\title{
Whirls of Faith and Fancy
}

\section{House Symbolism and Sufism in Elif Shafak's The Flea Palace}

\author{
Verena Laschinger \\ Universität Erfurt \\ verena.laschinger@uni-erfurt.de
}

\begin{abstract}
Elif Shafak's The Flea Palace (2004) exposes secularized Istanbul as a grotesque world. By establishing the apartment building as a synecdoche for the city and negotiating the characters' trajectories within the historical context of modernizing Istanbul, the novel presents their alienation as the sine qua non of the modern individual which is best confronted playfully or rather in the Sufi way. The argument is supported by the novel's complex employment of circles and lines as thematic and formal patterns which refer to Islamic ritual practice of the Mevlevi Sufis in numerous ways.
\end{abstract}

\section{Keywords}

apartment building - transnationalism - Turkey - Sufism - circularity

\section{Introduction}

Narrating the history of an apartment block and its resident community in contemporary Istanbul, Elif Shafak's 2004 novel The Flea Palace (originally published in Turkish as Bit Palas in 2002) can be classified as apartment fiction, a subgenre firmly established in the novelistic traditions of France, Turkey, the U.S., and across the globe. The Flea Palace presents characters of various cultural backgrounds, religious beliefs, and nationalities stranded in a "once grandiose", now run-down, roach-infested apartment building called Bonbon Palace (76). It employs the apartment building as a synecdoche for the city to expose modern and secularized Istanbul as a grotesque world. All characters are migrants of a kind and inhabit Istanbul as spiritual or geographical exiles, like strangers in a city of strangers. Negotiating their trajectories and ails within 
the historical context of modernizing Istanbul, The Flea Palace presents their alienation as the sine qua non of the modern individual which the novel suggests is best confronted playfully or rather, as I will go on to show, in the Sufi way. In the following essay I will elaborate that the text, which presents itself as satirical postmodern metafiction, actually gestures towards Turkey's spiritual heritage of Mevlevi Sufism as a means to mitigate the challenges of modern urban life. In my view, The Flea Palace embeds linear narrative sequences into a circular frame, with the circle being simultaneously encompassing and pervasive both thematically and structurally, to mimic the whirl of the Sufi dervishes at the so-called sama, or sema in Turkish. ${ }^{1}$

My access to Shafak's Turkish original is doubly constrained by language barriers, because I am a German reader of world literatures in English. Consequently, my analysis refers to Müge Göçek's English translation of Bit Palas which is certainly not identical with the Turkish original. However, I consider my dependence on translation symptomatic of the transnational exchange that is at the center of both Shafak's literary oeuvre and personal life. Because Shafak has been raised in France, Turkey, Spain, Jordan, and Germany, "[m]igrations, ruptures and displacements have played a crucial role in [Shafak's] personal history" (Shafak cit. in Chancy 56). Early on she experienced the gains of a cosmopolitan upbringing as well as the discomfort of living in a linguistic gap. Seeking to bridge this gap, Shafak started to commute between Turkish and English as her professional languages. Then a part-time resident of the U.s., the writer premiered in English with the The Saint of Incipient Insanities in 2004, joining "the growing group of international writers who write in English although it is not their mother tongue" (Oztabek-Avci 83).

From then on Shafak writes novels in English and consecutively publishes The Bastard of Istanbul (2006), The Fourty Rules of Love (2010), Honour (2012), The Architect's Apprentice (2014), and Three Daughters of Eve (2016). Her choice of English is considered a "cultural betrayal" by Turkish nationalist critics (Shafak cit. in Scharf), and Shafak has also been repeatedly accused of catering to a Western audience. In my reading I am going to focus on the (trans-)national politics and poetics of The Flea Palace rather than the marketability of Shafak's biography and bilingualism. The following essay will describe the function of the apartment building plot, before expanding the argument towards stylistic

1 In Mystical Dimensions of Islam Annemarie Schimmel calls the sama a "mystical dance" and "the most widely known expression of mystical life in Islam" (179). It "has found its most eloquent expression" in the work of the Persian poet Rumi who considered the sama "nourishment of the soul" (183). In Early Islamic Mysticism Michael Sells explains the "sama'/ (musical audition)" as a central aspect of Islamic ritual practice (25). 
and formal patterns in The Flea Palace which, I claim with reference to Ottoman Islamic heritage, discursively promotes Islam as a transnational social movement. ${ }^{2}$

\subsection{Building Bonbon Palace: The Story of Pavel and Agripina Antipov}

Agripina Fydorovna Antipova and General Pavel Pavlovich Antipov's illdoomed attempt to settle in Istanbul shall serve as the entry point for my discussion of The Flea Palace. ${ }^{3}$ In 1920 the refugees, former members of the White Russian nobility, arrive at the shores of the Bosphorus. Already displaced and dispossessed by the Bolshevic Revolution, the sudden death of their baby girl

2 Already in her debut novel Pinhan (1997), Shafak narrates the story of a hermaphrodite Sufi mystic. In The Fourty Rules of Love of 2010 Shafak models the protagonist after Shams of Tabriz, wandering dervish and spiritual mentor of Sufi mystic Mevlana Jalaluddin Rumi (1207-1273), whose followers founded The Mevlevi Sufi order in the Anatolian city Konya in 1244. Compared to Fourty Rules of Love, The Flea Palace is much more structurally complex and less direct in promoting Sufi mysticism as cure for the ills of modern life. Critical of Shafak's literary populism, Elena Furlanetto points out that by domesticating the figure of Rumi for an American audience in The Fourty Rules of Love, Shafak "not only succumbs to the oversimplification and decontextualisation of Rumi's work perpetrated by the American initiators of the Rumi phenomenon, but also employs Orientalist strategies in the ways in which she positions the East as being instrumental to the West" (201). While agreeing with Furlanetto's observations, I think that her criticism misses the point. As a fiction writer Shafak takes the liberty to fashion her subject according to her and her readers' needs. By popularizing Sufi mysticism as a gentle, spiritual version of Islam, which shares its core dogmas with Christian religions, Shafak's novels aim at a (Western) public deeply upset by radical Islamicism. While I do not want to insinuate that Shafak is a member of the movement, I do find that her fiction does in fact promote interfaith dialogue in the spirit encouraged by Fethullah Gülen, which "seeks to realize religion's basic oneness and unity, and the universality of belief" ("Interfaith"). Shafak's portrayal of Sufism shares with Gülen an understanding of religion as "embrac[ing] all beliefs and races in brotherhood, and exalt[ing] love, respect, tolerance, forgiveness, mercy, human rights, peace, brotherhood, and freedom" ("Interfaith"). The Gülen movement has become a crucial factor in transnationalizing Islam. Having gained "spectacular presence" all over "secularist Turkey, post-revolutionary Iran, and pluralist Europe" (3), Islam now "works as a horizontal social imaginary" (11), according to Turkish sociologist Nilüfer Göle.

3 Shafak engages Boris Pasternak's Doctor Zhivago (1957) as an intertext to The Flea Palace by naming her characters Agripina Fydorovna Antipova and Pavel Pavlovich Antipov. Inverting the Russian epic, Shafak has Pavel Pavlovich Antipov's wife wither away, while Pavel succeeds in making a home for himself in France and Turkey, symbolically entangling the two nations by his amorous and commercial operations. 
pushes Agripina over the edge and turns Istanbul into a site of horror for her. The couple leaves for France, where Agripina withers away in a mental clinic, while Pavel manages to regain his self-esteem and some of his wealth. He even fathers another daughter with a French woman. Pavel, who "had recovered all he had lost" (56), is ready to confront Istanbul a second time in the 196os. Along goes Agripina:

To this end, in spite of all the delay, he had to provide her with the opportunity to avenge the pain of those earlier days, by returning years later to the city where at such a young age she had been so scorned, trampled, belittled and defeated. He wanted to make sure this incomplete and stumpy tale would be completed in peace.

Palace 61

In an attempt to improve the condition of his depressed wife, Pavel bestows upon Agripina an "apartment building in an exclusive neighbourhood of the city" (61). His gift is meant to substitute for the child they had lost in Istanbul: "Agripina, here is your baby with the eyes the colour of ashes. ... She'll not abandon you as long as you do not leave her" (64). Setting out to claim the city that defeated them once, Pavel promises that his wife would not have to live in Istanbul "as a refugee or deportee or stranger or guest or tenant.... To make her a home there, he would first make her a homeowner" (61).

Pavel, who promises Agripina stability, adorns the façade of the apartment building with a meaningful relief. "[P]laced within a circle was a small-headed, large-bodied peacock" (63), posing with one of his feathers "heading to the sky and the other four in four separate directions", its head "bent down" towards "the tip of its feet" (64). While 'peacock' simply means 'adornment' in Arabic, as Idries Shah states in Tales of the Dervishes (137), the peacock relief of the buidling takes on a deeper meaning. Not only is the peacock's tail "[a]kin to Variation (talwin, literally 'coloring') in Sufism, where the self takes on various 'colors', as Sufi scholar Henry Bayman states, continuing that for "the Sufis the final goal is, rather, to achieve Stabilization (tamkin) - to be painted with 'the color of God' (sibgatullah)."

More significantly still, the peacock is represented in such a way that its feathers connect the sky and the earth, bringing to mind the dervishes's pose at the sama. Mindful of the circular movement of the cosmos, the Mevlevi Sufis perform whirling practice along a round path, while simultaneously rotating around their body axes. While whirling, the worshipper's arms are open, the vertical reach symbol of connectivity as "his right arm is directed to the sky, ready to receive God's beneficence; his left hand, upon which his eyes are fas- 
tened, is turned toward the earth. The semazen conveys God's spiritual gift to those who are witnessing the Sema" ("Sema"). ${ }^{4}$

While to Pavel the apartment building represents "Triumph" (Palace 64), Agripina feels less positive about it. Instead of "crown[ing] their success" with a name that demonstrated "how very different their second arrival in the city had been" (64), she insists on calling the building Bonbon Palace. Erected on the desecrated site of two former cemeteries, one Armenian Orthodox, the other Muslim, which were sacrificed in the flurry of urban renewal, Bonbon Palace, represents a tomb to memorialize all she had lost in Istanbul. "[U]nmoved at [sic] being back at the place where they had buried their baby" (62), Agripina thinks of the building as a sarcophagus to hold her spiritless body. Looking down upon Istanbul from her balcony, Agripina feels like floating in a sea of tombs:

She opened the double-panelled door and stepped out. The city was spread out right in front of her. It had changed ... and how ... She looked at Istanbul with the malicious pleasure of a woman who years later encounters the rival whose beauty she once secretly envied, now aged, decrepid and shrivelled [sic].

Palace 65

In Agripina's view - exile has in short succession deprived her of home, status, wealth, child, and finally her will to live - her misery is paralleled by the city's ruination. Founded as Constantinople to be the center of the East Roman Empire, Istanbul was designed for grandeur. As the center of the subsequent Byzantine and Ottoman Empires, the city changed its name, but kept its position as a world city until its status dwindled dramatically later in the nineteenth century. Along with its glory, Istanbul lost its administrative and representative functions under the political leadership of Mustafa Kemal Atatürk who made Ankara capital city of the Turkish Republic. Istanbul was degraded to become "a fairly typical Third World sprawl," Çağlar Keyder states (25). According to Keyder, the "old city retained most of its glory and the older neighbourhoods some of their charm, but the overwhelming impression was one of dilapidation and crowdedness" (25). In this urban landscape, the pompous Art Nouveau palace, which Pavel builds for his wife, seems awkwardly "placeless" (Palace 67), as if fallen out of time.

4 A detailed description of the sama, can be found in Hellmut Ritter "Die Mevlânafeier in Konya vom 11.-17. Dezember 196o". 
When Pavel's illegitimate daughter Valerie Germain inherits the apartment building in 1972, she finds Bonbon Palace "colourless and soulless" (67). Permanently settled in France, she decides to rent out all the flats in the building, and since she is "managing the business from afar" (66), she leaves it to the new tenants to dispose of anything the former tenants might have left behind. As it turns out later, Madam Auntie, who rents Pavel and Agripina's apartment, is incapable of throwing out their belongings. The young widow becomes Agripina's involuntary heir and has to accommodate herself with the Russian refugee's legacy, which entails both her material possessions and her melancholy. Burdened by Agripina's clutter, Madam Auntie inhabits the space as if it was not fully hers, and it in fact keeps her from fully living her life. Yet, since Madam Auntie mourns the death of her husband, her melancholy ties right in with Agripina's. Consequently, transgenerational gloom suffuses Bonbon Palace like the garbage smell that pervades the building, symbolizing both Agripina's and Madam Auntie's inability to deal with death, to mourn, then to let go, and to accept the cycle of life.

\subsection{Suffering in Bonbon Palace: The Story of Madam Auntie}

In the section of the novel set in 2002, Madam Auntie becomes the central character. By now she is the most senior resident of Bonbon Palace as well as the only Istanbullu:

[S]he had much older roots than anyone else, she was the only one among them who was born and raised in Istanbul. While most of the neighbours were immigrants, her entire life had been spent in this neighbourhood. Unlike the others, she had not popped up out of nowhere, turning her back to a future that never came and a past that was never left behind. Here she was, neither dragged along by others nor having dragged others behind her. Her name was "Auntie" because her very being was a residue of a past none of them had lived.

Palace 90

The "past none of them had lived" refers to the pre-Republican era, nostalgically perceived as a time before Istanbul was flooded by waves of migrants or drowned by modernizations that spared neither cultural nor religious heritage. Mourning the decline of the old city as much as the death of her husband, Madam Auntie withdraws into solitude. "[W]aiting for hours by the seaside", she picks up "what the sea would ferry to the shore" (345). She also steals trash off her neighbors' doors. For Madam Auntie, collecting garbage is a psychological necessity. As if she belonged to "the Guild of Seekers" (411) - forerunner 
of Istanbul's modern garbage companies established in 1868, Madam Auntie "would gather to sift through" (411). The garbage men, however, only "collected to throw away" (411). Described as a "steadfast safe-keeper", the old lady is "infuriated at the ease with which people dispensed with the objects of others" (403). A relic of Ottoman times, Madam Auntie "didn't belong to this age" (412). Living in a house of unhappy foreigners and Westernized secular Turks, the character is emblematic of a past, whose traumatic ending aggravates not just the tenants of Bonbon Palace. The novel infers that in modern, secular Istanbul pain is as pervasive as garbage.

Trapped in a state of pathological melancholy, a gloomy flat in an ill-doomed building and in an equally gloomy city, Madam Auntie has turned into a compulsive hoarder. In three rooms of her apartment she stacks up garbage hills. ${ }^{5}$ The rotting trash not only attracks cockroaches but also gives off a sour smell. Stirred by foul odors and vermin that pervade the entire building, the tenants of Bonbon Palace start to make inquiries. Finally, a child called Su (Turkish for water) detects the source of the stench. In accordance with the Sufi meaning of her name, the girl functions as a "vehicle of reintegration, or, from another angle, of liberation, for water is likewise a symbol of the Living Substance of Reality set free from the ice of finite forms" (Lings 78). Having befriended the recluse, the eleven-year-old accidentally stumbles across the trash piles in Madam Auntie's flat. Incapable of keeping the secret as promised, the child talks to her English tutor who, true to the novel's love for entanglements, turns out to be the narrator of the story who happens to also live in Bonbon Palace. He passes the news on to his mistress, tenant of flat number 8 , as well as to the reader so that it circulates freely. Once her disposophobia is exposed, Madam knows that the garbage piles will soon be cleared away. Afraid to let go of them, she decides to stop eating. When the public health authorities finally arrive to clean out the apartment, they find Madam Auntie dead:

When the door was broken, men with masks fully clad in white dashed inside. They placed the stinking corpse on a stretcher and carried it away. The old widow's corpse was so light, so petite ... the residue of a body that

5 The Flea Palace contains a number of references to Berji Kristen: Tales from the Garbage Hills by Latife Tekin. Published in 1984 and translated into English in 1993, Berji Kristen claimed considerable international success. It tells the story of Anatolian migrants in the 196os, who make their ramshackle homes on Istanbul's garbage hills known as gececondus. In The Flea Palace the theme reappears, but here garbage is a cipher for Turkey's forbidden Islamic Ottoman heritage the memory of which lays rotting, literally stinking up people's homes, and figuratively making toxic their individual relationships as well as national politics. 
had refused for days to eat-to drink-to take its pills ... Madam Auntie had not been half as resistant to thirst and hunger as cockroaches. As soon as the men departed, the flat was fumigated once again. The insecticide spray drizzled on the eggs of the bugs, as well as on the one hundred and eighty-one objects from the past.

Palace 426

In her attempt to arrest the past, Madam Auntie has finally become a thing of the past. With her body turning into one of the stinking objects stockpiled in her apartment, another circle is closed in The Flea Palace. Like Agripina, Madam Auntie lived an unhappy life entombed in Bonbon Palace, where her corpse is slowly and indiscriminately mixing with other matter in the recycling process "just like flies and cockroaches and food and objects, humans too have an expiration date. ... They rot and decompose, break apart and scatter, are no longer themselves and get muddled up with different things" (402), as the narrator dryly puts it, essentially expressing the "elementary law of all phenomena" as "developing, having a duration and being reabsorbed" that is central to Islam (Critchlow 7).

\subsection{Styling the Grotesque Building}

The events narrated in The Flea Palace cover the timespan from 1920 to 2002, which the novel divides into three historical units: first, the collapse of the Ottoman Empire at the beginning of the twentieth century; next the emergence and development of the Republic of Turkey up to the 1970s, when society was fervently secularized and the built environment modernized with equally aggressive fervor; and finally the Neo-Ottoman era, which started when the AK Party won the national elections in a landslide victory in 2002, boosting Turkey's globalizing economy as well as the nation's overt re-identification with Islam, and restructuring Istanbul "along neo-liberal lines" (Aksoy 228). ${ }^{6}$

6 While the role of religion remains a highly controversial subject in laicist Turkey, the political establishment of the Justice and Development Party's (AK Parti), large parts of Turkey's entrepreneurial class, and youth are openly devoted to (Sunni) Islam. From the outset critics have suspected the AK party to aim to revive Ottoman spiritual traditions as well as to increase Turkey's political engagement within the geographical expands of the former Ottoman Empire, although "it is difficult to substantiate claims that the AKP ever had a covert program to transform Turkey into an Islamic state grounded in sharia, or Islamic law" (Aykan qtd. in Pietrobruno 1265). Such suspicions were mainly directed towards Fethullah Gülen, preacher and founder of the global Gülen movement, who moved from being President Recep Tayyip Erdoğan's close ally to archenemy. Gülen, who was elected one of "the 100 most influential people in the world" by TIME magazine in 2013 (Kinzer), lives as an exile in the Us. 
Shafak reorganizes story-time into discourse-time by summarizing the events from 1920 to 2002 in an intricately woven tripartite first part, which relays Pavel and Agripina's washing up on the shores of Istanbul and the early history of Bonbon Palace within the context of the city's development in the Republican era. In the sixty-four episodic chapters of the main part, the narration focuses on life at Bonbon Palace in 2002. Here, the apartment building plot is elaborated in a decidedly grotesque fashion, to which it lends itself especially well as even a cursory look at transnational apartment fiction shows.

Dominating the urban landscape of nineteenth-century Paris, the apartment building has long "provided fiction writers with settings for farces, melodramas, supernatural tales," as Sharon Marcus states in Apartment Stories (2). Because it offers a "unifying frame for heterogeneity" (2), a variety of "vantage points for visual observation and exhibition, nodes of commercial and sexual exchange, and settings for the sensory overload and chance encounters associated with crowds" (3), it was especially popular with French writers Zolà and Balzac:

The apartment-house plot represents the city in microcosm, exhaustively exploring a single residential setting that comes to stand for the entire urban fabric; in a usually comic register and toward generally happy ends, the apartment-house plot repeatedly stages exchanges between private spaces, so that the boundaries between individual apartments dissolve into a larger, more porous, and more public space.

MARCUS 61-62

Over the decades and across nations the apartment house plot attracted many authors. Among them are American writers Edward Lewis Wallant (The Tenants of Moonbloom, 1963) and Berhard Malamud (The Tenants, 1971), British writer J.G. Ballard (High-Rise, 1975), and more recently the American cartoonist Chris Ware, who pushed the conventions of the subgenre by way of his 14-piece graphic novel in a box entitled Building Stories (2012). Manil Suri's The Death of Vishnu (2001), as well as Alaa Al Aswany's The Yacoubian Building (2004, first published in Arabic in 2002), turned out massively successful with mainstream audiences in the U.s. and Europe. Aiming to expose rampant political corruption in postcolonial societies, the texts are set in Bombay and

He teaches a moderate form of Islam based on Sufism as "the spiritual dimension of Islam" (Gülen, "Suf", my translation). In 2016, he was accused of plotting to overthrow the government in Turkey. 
Cairo respectively, imbued with exotic local color, graphic sex scenes, and comical gusto by their Indian-American and Egyptian authors. While Shafak's novel shares these features, it also emulates some of the formal ambitions of Georges Perec's apartment fiction masterpiece Life: A User's Manual (1978, trans. 1987), to which I will return below.

The building in Shafak's novel takes on symbolical meaning. Following Gaston Bachelard's The Poetics of Space, I understand it as a "psychic state" (72). Consequently, I draw inferences from how it is described to the condition of those who inhabit it as well as to the urban landscape within which it is set. Designed in the 196os by Russian migrant Pavel Antipov - a resident of both Istanbul and Paris, the apartment building central to The Flea Palace is located in Beyoğlu, a neighborhood on the European side of the city known to accommodate Istanbul's foreign, non-Muslim residents. Forty years later, in the main part of the novel, Bonbon Palace houses various migrants. As victims and agents of change, they have turbulent transnational biographies which The Flea Palace narrates along with the building's history. Expressive of the house community's cultural diversity characteristic of transnational contact zones to borrow an expression from Mary Louise Pratt - Bonbon Palace sports eclectic stylistic features:

The most striking characteristic of the building was that no two storeys were alike, having been constructed upon Pavel Pavlovich Antipov's insistence in Art Nouveau style, even though no longer in fashion. As if to compensate for their lack of balconies on the facade (sic), the flats at the entrance had much larger windows than the rest. The balconies too changed from one floor to the next. ... So striking were the differences that one could not help but think the residents of the building shared the same space without living in the same place.

Palace 63

Architecturally, Bonbon Palace is reminiscent of the so-called "National Architecture Renaissance" - first-wave architectural modernism that according to Sibel Bozdoğan was dominant in Turkey during the first three decades of the twentieth century (18). Quickly succeeded by "Yeni Mimari, the New Architecture" (295) whose functional and rationalist aesthetic agenda was strongly influenced by "celebrity figures of modernism such as Le Corbuier [sic], Walter Gropius, and Mies van der Rohe" (295), the palaces of the National Architecture Renaissance signify a short period in the early phase of the Turkish Republic, in which the integration of Ottoman and Western styles was attempted: 
The basic idea was to combine decorative elements derived from classical Ottoman architecture (especially semispherical Ottoman domes, wide roof overhangs with supporting brackets, pointed arches, and ornate tile decoration) with beaux-art design principles (symmetry and axiality, in particular) and new construction techniques (reinforced concrete, iron, and steel).

BOZDOĞAN 18

Bonbon Palace adheres to features that were no longer stylish by the time of its construction in 1966. By implication, the apartment building represents the idea of an integrated, multicultural society as equally outdated. This can be concluded from Nağihan Halioğlu's comment on the specific weight, which the appellation "palace" carries:

As inventions of a new age, this was the name given to apartment blocks in the 1930s to evoke a sense of opulence, which indeed these blocks harboured in their heyday. However, with the advent of new electrical and plumbing amenities in the following decades, these "palaces" of the Republic were themselves abandoned, like the abandoned "real" palaces of the Ottomans. These beacons of modernity fell into disrepair and became cheap accommodation for all sorts of city dwellers.

HALILOĞLU 391

Already an anachronism at the time of its construction, fictional Bonbon Palace eventually also loses its allure like the real palaces of both the Ottomans and the Turkish Republic. By 2002 it harbors neither "a sense of opulence" nor any promises of integration for its tenants. They might be living under the same roof but are worlds apart. As "one could easily sit in the apartments without worrying about being seen from the outside" (Palace 63), the tenants of Bonbon Palace are basically isolated in their own idiosyncratic niches. They acknowledge the others' presence only on account of their irritating behaviors. These are symbolized in the text by odors and bugs, which - much to everyone's dismay - infest the building and wander unrestrictedly across flats and floors.

Like Emile Zolà in his naturalist apartment novel Pot-Bouille (1882), Shafak rummages through the literal and figurative filth in each flat, relaying the tenants' intermingling histories in the process. As already mentioned, Madam Auntie's apartment is exposed as a hoarder's nest. Likewise uncovered are the other tenants' pathologies. They range from obsessive-compulsive-disorder to delusion, from anxiety to phobia to auto-aggressive behavior and alcoholism. Bonbon Palace resembles an "insane asylum" (Palace 404), where Turks and 
foreigners, Muslims and non-Muslims, illiterates and educated people cohabitate and clash. Bearing the consequences of war and migration, Westernization, and compulsory Kemalist secularization, the tenants of Bonbon Palace are not at ease with the past or the present. Clearly, there exists no quick therapeutic fix for their psychopathologies.

Inexhaustive as a narrative setting and vehicle to map the psychotopography of the modern city, the apartment plot is employed in The Flea Palace to explore the complex, contradictory social relations in contemporary Istanbul against the backdrop of modern Turkish political history. The narrative voice clearly takes a critical stance in employing the apartment plot in conjunction with the garbage theme, which bespeaks the novel's grotesque mode. Especially in the main part, the disintegrated and foulsmelling Bonbon Palace becomes an arena of overwhelming moral and sexual decadence - a sick and sickening space very much in need of cleansing. It betrays signs of an "alienated world," an expression coined by Wolfgang Kayser to describe the grotesque (my translation, 198). ${ }^{7}$

The tenants produce a fair amount of happy hullabaloo. Mostly they meet the dread that permeates their routines and interactions as families, neighbors, and citizens with makeshift survival tactics and neurotic antics. Their cheerful going-on - best portrayed in hilarious scenes set in the ground floor apartment, the hair salon of twin brothers Celal and Cemal - resembles a circus show. ${ }^{8}$ Likened to fleas, which the reader observes performing their jolly stunts,

7 Like the eponymous novel, the apartment building is called bit palas in the Turkish original. Translating as louse palace, the title nods to the Arabian Nights. More precisely, it refers to the "Kalîla wa-Dimna - the Arabic work based on the Pancatantra", which according to Daniel Beaumont, frequently employs the opening phrase: "If you're not careful, that which happened to the louse and the flea will happen to you" (3). The personification of vermin as inhabiting a magnificent building can also be seen as foreshadowing Shafak's use of the grotesque. Furthermore, the oxymoronic bit palas alludes to the Turkish term bit pazarl, which translates as flea market into English. Unfortunately, both the assonance between palas, which etymologically derives from French, and pazar, as well as the signification of flea market as a haphazard place of commerce, or bazaar, where second-hand items, junk as well as antiques are traded mostly outdoors, under makeshift conditions, and often by and to a multicultural people, are lost in the English translation. While the original Turkish title establishes a link between the apartment building and the garbage collecting Istanbullu Madam Auntie, the English name of the building implies a closer connection to bonbon-loving Russian migrant character Agripina. Thus it not only shifts emphasis from one to the other character and storyline, but also away from the grotesque aspects of the building.

8 Already in The Gaze (2000, English translation in 2004) Shafak employs the grotesque mode and the circus theme. Exploring the ramifications of obsessive looking in contemporary culture, Shafak's male dwarf character records the prevalence of myths and stories concerned with visuality in his Dictionary of Gazes. Furthermore, incidents of sanctified voyeurism are 
The Flea Palace employs the tenants' carnival spirit to point at the "contradictory and double-faced fullness of life," which Michail Bakhtin considered the "essence of the grotesque" (62). This spirit corresponds to the conversational tone and the light, quick pace in which the story is narrated. Yet, while The Flea Palace comes across as an easy read, the mismatch of tone and topic is in fact what James Goodwin in Modern American Grotesque calls a "formal property of the grotesque" (2). Allowing for "the simultaneity of laughter and horror" (2), the resulting ambivalence is calculated to serve a higher end. According to Bakhtin, it counters the hegemonic discourses and institutions. The "reductiveness one can associate with the grotesque", Goodwin states, "is not in the end a matter of oversimplification but rather a radical procedure intended to disclose meanings otherwise obscured from apprehension" (2).

When Madam Auntie, the novel's emblematic Ottoman, sifts through the trash, Islamic heritage literally becomes a signifier of lost treasure in the text. In order for "the city to modernize the order of things had to be capsized", and "things that should not have been thrown away," were trashed in the Turkish Republic (412), as the narrator contends. Shafak even imagines a belligerent scenario in which Kemalism symbolically sets out to destroy every last bit (or, bit - note the double entendre) of the Islamic-Ottoman heritage and past, by making a vengeful character called Injustice Pureturk douse Madam Auntie's apartment. Named Öztürk in the Turkish orginal, the owner of the "Rainbow Pest Removal Service" (12), who fumigates the flat with pesticide, is a reference to the Kemalist Öztürkçe-movement. ${ }^{9}$

However, in The Flea Palace such efforts are ridiculed. Measuring only "one metre and forty-three centimetres in all" (Palace 12), the "ginger haired, funnyfaced, flap-eared" man, who feels mocked by the course of history and compensates his complexes by exterminating unwanted creatures (419), is a grotesque character. Summoned to pursue the wish of purification like a jinn in a bottle,

presented to elaborate on the consequences of visual objectification. The true horror of the story, however, almost goes unnoticed. The sexual abuse of a three-year old girl by an adult stranger is only brought to light with the grown up victim narrating allegories and fairy tales, which open interstices for repressed memory to appear. The Gaze gives a voice to the obese victim's trauma, which is hidden from those too busy mocking her physical appearance and denied by those closest to her. The novel exposes the monstrosity of a society, which fetishizes visual exposure, but which is incapable of seeing its own shortcomings and failures. Less central in The Flea Palace, the grotesque indicates to which degree alienation is habitual in modern day Istanbul.

9 Börte Sagaster also discusses Shafak's creative use of language who, defying Atatürk's Öztürkçe language reform, intentionally includes Arabic and Persian vocabulary of Ottoman Turkish provenance (277). 
he actually gets mistaken for "a genie" by a horrified child at Bonbon Palace (11, 420). But his brutal cleansing of Madam Auntie's apartment fails and in due time some eggs will hatch and continue the cycle of life as is indicated in a chapter headlined "The Boyar and His Lover" (426). Embedded as a disparate element in the story cycle about Bonbon Palace, the animal fable tells the story of two cockroaches personified as Russian nobility and survivors of a gas raid..$^{10}$

True to the tradition and manner of Turkish storytelling, The Flea Palace employs the house as setting to carve out meaning and make visible the conflicts that aggravate society. According to Carel Bertram whose Imagining the Turkish House: Collective Visions of Home interrogates the complex, contradictory history of house representations in modern Turkish fiction, the old wooden house for example marks what was lost in the transition from Ottoman to Republican life. Functioning "as symbols for ideas related to the past, such as spirituality" (4), representations of the wooden house are simultaneously "poetic expressions of longing for a lost past, voices of a lived present, and dreams of an ideal future" (9). In modern Turkish literature the Ottoman-style house transmits the idea of equality, of a newly imagined national identity "that bound all Turks together by a common memorial heritage in spite of demographic data to the contrary" (10). By "the 1930s", Bertram concedes, "cultural identity, the term Turkish, and the old wooden house became permanently merged in the Turkish imaginary" (189).

Nobel laureate Orhan Pamuk's Istanbul: Memories of the City (Turkish original published in 2003, English translation in 2005), which renewed awareness for the Turkish metropolis among readers across the world, is among the best-known accounts on the emotional weight of Istanbul's wooden houses. Pamuk's narrative alter ego remembers, for example, how the magnificent summer residences ( $y$ alıs) lining the shores of the Bosphorus were frequently incinerated during his childhood in the 195os and 6os. His recollection of the crowd rushing to the fires in excitement at the time is contextualized by the text's exploration of hüzün. According to the first-person narrator, this distinct sort of pervasive melancholy derives from "the guilt, loss and jealousy we feel at the sudden destruction of the last traces of a great culture and a great civilization that we were unfit or unprepared to inherit in our frenzy to turn Istanbul into a pale, poor, second-class imitation of a Western city" (191).

10 Shafak resorts to Arabian /Islamic mythology to interrupt a thoroughly mundane situation in secularized Istanbul with the fantastic element of the jinn, a supernatural spirit creature often mentioned in the Quran. Similarly, "The Boyar and His Lover" is an allusion to the Arabian Nights in which animal fables are used as "truthful' simulations" to relay an "educational message" (Chraïbi 8). 
In this memoir Pamuk contrasts the wooden house with the apartment building. The five-storied building called "Pamuk Apartments, in Nişantaşı" (3) is made an example of this "frenzy" to westernize. For the young narrator it serves as vantage point of his frenzied coming-of age. Troubled to find his cultural identity in a city where living like westerners comes "at the cost, it seemed, of unbearable soullessness and artificiality" (279), he can only return to the Pamuk Apartments "fifty years on" (5). Once he has matured and made peace with his city's past and his cultural identity, the apartment building can be his refuge and true home.

Employed in fiction the apartment building still reverberates the meaning of the house symbolism codified in Turkish literature as speaking to national politics and cultural identity. However, compared with the Ottoman-Turkish wooden house - be it a street mansion (konak), a garden residence (köşk), or a house at the waterfront $(y a l)$, it is not emotionally loaded as signifying nostalgia. Instead it works more cerebrally, serving to contain conflicts and transformations of a multiethnic and multireligious community in the new Turkish Republic as in the case in Memduh Şevket Esendal's Ayaşlı ile Kiracıları (Ayaşlı and His Tenants). Set in Ankara, the 1934 apartment text serves as an intertext to Shafak's The Flea Palace (Sagaster 278).

Yet, Shafak's grotesque mode cuts deeper than Esendal's irony, making The Flea Palace both a distinctly Turkish and a powerful transnational city novel. The grotesque is employed to elaborate the toll that Kemalist secularism takes of those who inhabit contemporary Istanbul. The fact that the multicultural characters' circuits and contexts are extended across national borders turns their spiritual vacuum into the conditio humana of a modern world. Furthermore, the grotesque is itself a symbol of spiritual Islam. In The Flea Palace it consequently serves both a different and less obvious purpose (at least to a reader unfamiliar with Islam). "Called jam' al-azdad in Sufism", the grotesque functions as a "conjunction of opposites" in the novel (Bayman). As a conjunction it allows for paradoxes and simultaneity of opposites such as motion and stasis, circularity and linearity, laughter and horror, because only "when opposites are reconciled and integrated can the Multiplicity (kasrah) of this world fall away, revealing Unity (wahdah)." While it alludes to Islam stylistically, the grotesque unfolds its full function in conjunction with the novel's distinctive patterning. Shafak uses the circle and the line as pervasive thematic and structural patterns of The Flea Palace to gesture yet again toward Islamic practices of ritual performance and storytelling. 


\subsection{The Inner Story Cycle}

Nodding to the Arabian Nights, Shafak crafts the novel skillfully by embedding a narrative into a frame story that is itself patterned as a circle. The inner story cycle is an array of sixty-four vignettes, each of which zooms into a different apartment of Bonbon Palace. The headlines of all (but two) episodes start with the words "flat number" followed by a figure and the names of the respective tenants of Bonbon Palace, where all characters meet and around which all action and (e-)motion revolves as if in a circle. As the narrator states, the building in "all its dazzling beauty" has been established upon older layers of the city (63). Erected "with flats on top of one another with two layers of cemeteries underneath and seven planes of skies above" (442), it assumes itself the shape of a vertical line.

Functioning as "axis mundi" to which all characters are drawn and toward which the entire narrative process is oriented, Bonbon Palace is a secular version of the Kaba, if you will, "the Muslim sacred house of God" in Mecca (Sells "Spirituality" 215), which "point where the world and the transcendent meet" (Mysticism 14). The narrator himself literally circumambulates Bonbon Palace: "At the beginning I used to draw circles around Bonbon Palace, brief walks that did not end up anywhere. Step by step the circles started to widen" (Palace 429). The apartment building reaches towards the sky, while it is deeply anchored in urban history and ideologically and emotionally suffused by it. Built atop a palimpsest of oddly agglomerated houses, cemeteries, and layers of mixed material to which each generation of urban dwellers added its share, Bonbon Palace reverberates the multiplicity of former generations. Consequently, it lures the restless spirits of migrant characters with a promise "of permanence" (442). Such is the promise that Pavel Antipov makes to Agripina. Such is Madam Auntie's dream.

Yet, Bonbon Palace is a temporary home at best and characters arrest their continual transnational migrancy only temporarily to settle for a while. Even though their "paths led here at one stage of their lives: Istanbul, initially a port of escape enabling people to run away from everything, would herself become a reason for escape" (53). Eventually, the narrator states that they seek salvation elsewhere (53). For a number of characters Madam Aunie's death functions as a catalyst as announced in the introduction: "In the spring of 2002, in Istanbul, one among us died before the time was up and the line closed into a complete circle" (9). For example Nadia Onissimovna - tenant of apartment Number 6 packs up to go back "to the Ukraine" (418), leaving behind her philandering Turkish husband. Disagreeing over questions of faith, another character called 
"Ethel, the Cunt" breaks up with her misogynist lover, professor of Western philosophy, who later turns out to be the story's unreliable narrator (149). Separated as children, the identical twins Celal and Cemal reunite in Bonbon Palace after Cemal's return from Australia.

Completing the stories of numerous characters in return narratives, The Flea Palace seems to suggest that they might be better off in their native places. Here, the novel could be misread as disavowing the possibility of permanent integration in the city under the conditions carved out since 1923. In my view, however, The Flea Palace does not ruminate on the idea of a future Istanbul untroubled by migrants. Instead, it presents migration as a modern condition, in which waves of people are forced to continuously wander and be arrested time and again in shorter static phases. The novel's central geometrical motif is reiterated by the characters' transnational trajectories which are not only imagined as a continuous interplay of stasis and motion but also presented as circular story lines that are incorporated into an embedded narrative.

\subsection{The Outer Frame}

Composed as a stories containing story within a story, the novel toys with geometry in the following way. The introduction is succeeded by two more prolegomenous chapters entitled "Before ..." (17), and "Even Before ..." (37), each going further back in time in each to add depth to characters and issues previously mentioned. In the main part which is entitled "And Today ..." (69), the narration settles on the year 2002. Told in the narrative present, while bearing the title "Next ..." (439), the conclusion ties back in with the introduction. It not only picks up loose thematic ends by resuming the introduction's philosophical meditation on the transitoriness of time and space but also dissolves the novel's chronology and the sense of linear progression it retained despite earlier forays into the past. Closing the frame in a metafictional spin, the last chapter bends the novel's logical trajectory into a loop.

Having followed the narrator - whose consciousness the complete narrative is internally focalized on - down the rabbit hole where countless intertextual and cross-references of characters, locations, and events are scattered to form a complex tale, the reader emerges to realize that it was apparently all a metafictional sham. It turns out that the narrator of The Flea Palace - and here is the nod to Scheherazade - kept his readers in the loop only to keep himself entertained by his fabulations: "I cooked up this story basically to overcome my bug phobia" (443). Identifying as the professor of political philosophy who we know is a tenant of Bonbon Palace, the narrator was detained at the May 1st protests, currently serving a "one year and two months" prison sentence 
(443). Along with his current whereabouts he confesses his alcohol addiction and hence his unreliability.

Revealing himself as a game-playing joker in this confessional moment, he closes the parabolic frame opened in the introduction. Here he likens his storytelling to an outdoor game that was popular among the children of Istanbul "back in the old days" (8), who entertained themselves with the round lids of garbage cans: "four different segments would be chalked on the round lid with a separate word corresponding to each direction" (8). Given a spin, the lid eventually comes to a halt with the segment facing upwards providing the answer to a question posed in advance. In order to come up with a story, at least four spins are necessary. Each time the lid is arrested it provides an answer to one of the four essential aspects of storytelling: the time frame of the narration, the place, the protagonist, and the outcome (9). The children of Istanbul, the narrator muses, loved this game of random storytelling, which he refers to in order to emphasize the playfulness of his own storytelling. To him the "logic of the Garbage Game" (9), expresses "the playful element of life", which coincidentally (or not) is also the typical mode of the grotesque (Bakhtin 40).

Read as a metafictional commentary, playfulness also appears as the general story's core characteristic. Like Georges Perec's Life: A User's Manual, The Flea Palace points the reader towards the game it is playing." ${ }^{.1}$ As if following Perec's instruction to "play with space" ("Space" 85), Shafak constructs her apartment story with geometrical tools. Just as Perec includes small sketches of puzzle pieces in the preface of his text, Shafak's sports drawings of lines and circles as well as peritexts to prime the reader's attention (Palace 7,8$)$. Invoked both verbally and graphically the circle suspends the ending of the narrative: "You can plunge into the circle from anywhere you want, as long as you do not confuse that point with a beginning. No start points, no thresholds, no endings" (8), as the narrator states before he exposes Istanbul as a grotesque world.

The narrator's hoax throws the reader back to an interrogation of truth and nonsense in the beginning during the narrator's musing on circular storytelling. "[N]onsense," he declared then, is said to function in such a way that "it solders deception and truth to each other so much so as to make them indistin-

11 Into the preface of his text Perec "weaves a tacit analogy between the puzzlemaker and the author, the puzzler and the reader, simultaneously choreographing how the reader should encounter his text. As puzzlers, readers are empowered to craft their own narratives, but are reminded that meaning and understanding will always emerge from the dialogical relationship with the author" (Kulper 157). With the puzzle employed as a brilliant conceit, Perec's text adheres to radical formal constraints due to which a structure surfaces from the text's sprawling, puzzling, and seemingly arbitrary assemblage of lists. 
guishable" (7). Repeating the exact same phrase 434 pages later, the narrator leads the reader to believe that any criticism articulated in the course of the story is supposedly a "lie" (442), or rather nonsense. In this case, the repetition of words, a common literary device to generate suspense and humor, helps facilitate the novel's narratological circuit of "returning to the beginning rather than reaching a decisive end" (443). As a result, deception and truth become indistinguishable. However, when it comes to explaining the purpose of the novel's circular semiotics the unreliable narrator is yet again not to be trusted.

Claiming to make up his characters' joy and misery solely for his own sake, the narrator is not only a jerk for shaming his reader who takes delight from the story's grotesque crassness. Wishing to present his satire as pointless, the narrator is also a coward. In the light of my earlier elaborations, however, I do not consider this character assessment astute or compatible with the novel's political concern. In my view, the narrator's ambiguity - he could be a harmless clown or a dangerous critic - is a strategic pretense of appeasement. It keeps the reader in a metafictional limbo, while keeping the author safe from sanctions. ${ }^{12}$

\subsection{Framed by Evidence}

When Bit Palas was published in 2002, any criticism of Turkish secularism or open appeal for a greater commitment to Islam was met with great suspicion by Kemalist state powers. In many cases it was also reprimanded. While neoOttomanism, according to Keyder, became the master narrative only later, public interest in recuperating the Ottoman-Islamic heritage and the renaissance of Sufism, however, started to gain momentum around this time (27). The AK party under then Prime Minister Erdoğan's leadership made Neo-Ottomanist nationalism and religious conservatism a central issue. Widespread in the Ottoman Empire, the original Mevlevi Sufi lodges were closed upon the foundation of the Republic of Turkey due to the secularist purging policies of Mustafa Kemal Atatürk in 1925. Allegedly stripped of its religious essence, the sama reappeared in the 1950s as "a cultural event" (Aykan cit. in Pietrobruno 1265). Up to this day it is one of the most popular tourist entertainments in Turkey.

12 In 2006 Shafak was prosecuted for offending Turkishness due to acknowledging the Armenian genocide in The Bastard of Istanbul. Advocating freedom of speech in Turkey, human rights activists - both national and international - rallied in defense of this Muslim woman writer with an itinerant international biography, who addressed controversial sexual and political issues, and virtually turned Shafak into an international celebrity (Ermelino 29). 
But even as a culture rendition the sama, which has been enlisted as Turkey's intangible cultural heritage by UNESCO in 2005, "is more a prayer than a dance" (Pietrobruno 1264).

While I would not go so far to claim that The Flea Palace exposes the results of Kemalist laicism to aggressively promote a Neo-Ottoman sentiment, I find its manifold allusions to Islamic mysticism, especially to the Mevlevi Sufi whirling, intriguing. Playfully executed and emphasized in thematic patterning and stylistic features, the salient idea of the multidimensional novel even lurks behind the narrator's pose as a player. The narrator is allegedly modeling his story according to the Nietzschean concept of "Eternal Recurrence" (443), where the comedic, the tragic, and all of life "persistently repeats itself" (443). His fondness of circles can also be understood in spiritual terms. Throughout the story he activates geometric patterns which in Islamic art are supposed to draw "attention away from the representational world to one of pure forms, poised tensions and dynamic equilibrium" thus "giving structural insight into the workings of the inner self and their reflection in the universe" (Critchlow 8).

Redirecting the reader's attention from representation to form, the narrative thus allows insights into the workings of the narrator's inner self. What figures is an ambiguous character transitioning between atheist philosopher and believer, defined in Islam as a person who performs ritual Islamic practice (see Sells on the relation of physical performance and spirituality in Islam). While the narrator might not admit to being on a spiritual quest, both his storytelling and his strolls through Istanbul are presented in terms of geometry. Given that the circle in Islam is "the symbol par excellence for the 'origin' and 'end' of both geometric and biomorphic form" and hence "the primary cosmological symbol, one of wholeness and unity" (8), it appears that the narrator, who is deeply unhappy with his life, practices circular storytelling as a cure for himself and for the characters of his sick city narrative. ${ }^{13}$ The novel's employment of ambivalence and ambiguity clearly asks for a reading that distinguishes between what the narrator says and what he does (and what his story does). Therefore, I conclude that the narrator hides behind a strained intellectualism while narratologically performing whirls of fancy and faith in the quest for spiritual cure.

By way of a two-tiered narrative strategy, The Flea Palace not only discloses the critical situation of Istanbul's secular society - or else the modern condi-

13 The circle is also an important symbol outside the Islamic world. According to Ralph Waldo Emerson, it "is the highest emblem in the cipher of the world." Drawing from Islamic, Buddhist and Hindu spiritual sources and mystic traditions in his essay "Circles", the nineteenth-century American transcendentalist describes "the nature of God as a circle whose center was everywhere, and its circumference nowhere." 
tion - but also suggests handling it in the Sufi way. Conjuncting Sufism with Nietzschean philosophy and postmodern literary techniques, the novel is, I claim, ultimately a joyful, playful, (post)modern celebration of "the fundamental formula of Islam - 'la ilaha illa 'llah ('no divinity if not the sole divinity')" in the format of fiction. Crafted according to geometrical patterns which are expressive of exactly this fundamental formula as "no God but God; no part without whole; nor reflection without source ..., no dimension without all dimensions" (Critchlow 7), The Flea Palace engages the reader in a whirl of faith and fancy performed by Elif Shafak as a female whirling writer. ${ }^{14}$

\section{Acknowledgements}

I thank my reviewers as well as Beate Hampe and the participants of the TZM colloquium at Erfurt University for their helpful comments on earlier versions of this paper. I also want to thank my former literature students at Fatih University Istanbul who invited me to a book reading with Elif Shafak. Seeing these young devout Muslims' excitement for Shafak's fiction made me aware of the spiritual dimension of her work.

\section{Works Cited}

Aksoy, Asu. "Istanbul's Worldliness." Public Istanbul: Spaces and Spheres of the Urban. Eds. Frank Eckardt and Kathrin Wildner. Bielefeld: Transcript, 2008, 215-32.

Al Aswany, Alaa. The Yacoubian Building. Trans. Humphrey Davies. London: Fourth Estate, 2011.

14 While the sama originally is "an ancient male performance" (1265) rooted in patriarchal religious traditions of the thirteenth century, there are records of female whirling dervish performances, which Pietrobruno argues should be acknowledged as "emblematic of national identity" (1268). On YouTube, user-generated videos show Emine Mira Hunter's dervish performance at a Mercan Dede concert in Istanbul as well as performances of the Foundation of Universal Lovers of Mevlana in Istanbul, which in 1993 under its spiritual leader Hasan Dede "permitted women to take part in public performances of the sema alongside men" (1269). Such videos of the female whirling dervish are indicative of an "adoption of Sufism by secular individuals" in urban centers (Taji-Farouki cit. in Pietrobruno 1267). Here, an increasing number of people cherish the fact that "[c] ombined with secularism, Sufism enables a connection to Islam that diminishes the constraints of rigid gender segregation and patriarchal norms" (Pietrobruno 1267). While she assumes the role of a female dervish writer, Shafak also honors the matriarchal line of storytellers in her family ("Politics"). 
Bachelard, Gaston. The Poetics of Space. Trans. Maria Jolas. Boston: Beacon, $195^{8}$.

Bakhtin, Michail. Rabelais and His World. Trans. Helene Iswolsky. Bloomington: Indiana UP, 1984 .

Ballard, J.G. High-Rise. London: High Estate, 1975/2014.

Bayman, Henry. "Alchemy and Sufism." 17 Aug. 2014. Web. 3 Aug. 2016.

Bertram, Carel. Imagining the Turkish House. Collective Visions of Home. Austin: University of Texas Press, 2008.

Beaumont, Daniel. "Literary Style and Narrative Technique in the Arabian Nights." The Arabian Nights Encyclopedia. Ulrich Marzolph, Richard van Leeuwen, Hassan Wassouf. Vol. 1. Santa Barbara: ABC Clio, 2004, 1-5.

Bozdoğan, Sibel. Modernism and Nation Building. Turkish Architectural Culture in the Early Republic. Seattle and London: University of Washington Press, 2001.

Chancy, Myriam J.A. "Migrations. A Meridian Interview with Elif Shafak." Meridians: Feminism, Race, Transnationalism 4:1 (2003), 55-85.

Chraïbi, Aboubakr. "Situation, Motivation, and Action in the Arabian Nights." The Arabian Nights Encyclopedia. Vol. 1. Ulrich Marzolph, Richard van Leeuwen, Hassan Wassouf. Santa Barbara: АвC Clio, 2004, 5-9.

Critchlow, Keith. Islamic Patterns: An Analytical and Cosmological Approach. London: Thames \& Hudson, 1983.

D'haen, Theo and Iannis Goerlandt, eds. Literature for Europe? Amsterdam, New York: Rodopi, 2009.

Eckardt, Frank and Kathrin Wildner, eds. Public Istanbul. Spaces and Spheres of the Urban. Bielefeld: Transcript, 2008.

Emerson, Ralph Waldo. “Circles.” Essays: First Series. 1841. Web. 24 Mar. 2014.

Esendal, Memduh Şevket. Bütün Eserleri, Ayaşlı ve Kiracıları. Ankara: Bilgi Yayınevi, $1934 / 1983$.

Ermelino, Louisa. "East Meets West." Publishers Weekly 253: 48 (2006), 28-29.

Furlanetto, Elena. “The 'Rumi Phenomenon' Between Orientalism and Cosmopolitanism: The Case of Elif Shafak's The Forty Rules of Love." European Journal of English Studies 17:2 (2013), 201-213.

Goodwin, James. Modern American Grotesque. Literature and Photography. Columbus: Ohio State UP, 2009.

Göktürk, Deniz, Soysal, Levent, and Ipek Türeli, eds. Orienting Istanbul. Cultural Capital of Europe? London, New York: Routledge, 2010.

Göle, Nilüfer. "Islamic Visibilities and Public Sphere." Islam in Public. Eds. Nilüfer Göle and Ludwig Ammann. Istanbul: Istanbul Bilgi UP, 2006, 3-43.

Göle, Nilüfer and Ludwig Ammann, eds. Islam in Public. Istanbul: Istanbul Bilgi UP, 2006.

Gülen, Fethullah. “The Necessity of Interfaith Dialogue." The Fountain Magazine 1 Jul. 200o. Web. 3 Apr. 2014. 
Gülen, Fethullah. "Was ist ein Sofi bzw. Sufi?” Fethullah Gülen. 6 Aug. 2004. Web. 2 Apr. 2014.

Haliloğlu, Nağihan. "Memories of the City: The Metropole as Significant Other in Elif Shafak's Flea Palace and Orhan Pamuk's Istanbul." Literature for Europe? Eds. Theo D'haen and Iannis Goerlandt. Amsterdam, New York: Rodopi, 20o9, 387401.

Kayser, Wolfgang. Das Groteske. Seine Gestaltung in Malerei und Dichtung. Tübingen: Stauffenburg, 1957/2004.

Keyder, Çağlar. "Istanbul into the Twenty-First Century." Orienting Istanbul. Cultural Capital of Europe? Eds. Deniz Göktürk, Levent Soysal, and Ipek Türeli. London, New York: Routledge, 2010, 25-34.

Kinzer, Stephen. “The 2013 Time 100: Fethullah Gulen.” TIME 18 Apr. 2013. Web 26 Aug. 2014.

Kulper, Amy Catania. "Encountering the List. Georges Perec and the Archive as Spatial Paradigm." Candide: Journal for Architectural Knowledge 3 (2010), 137-167.

Lings, Martin. What is Sufism? Berkeley and Los Angeles: U of California P, 1975.

Malamud, Bernhard. The Tenants. New York: Farrar, Straus and Giroux, 1971.

Marcus, Sharon. Apartment Stories: City and Home in Nineteenth-Century Paris and London. Berkeley, Los Angeles, London: University of California Press, 1999.

Marzolph, Ulrich, Richard van Leeuwen, and Hassan Wassouf. The Arabian Nights Encyclopedia. Vol. 1. Santa Barbara: ABC Clio, 2004.

Oztabek-Avci, Elif. "Elif Shafak's The Saint of Incipient Insanities as an 'International' Novel." ARIE L: A Review of International English Literature 38:2-3 (2007), 83-99.

Pasternak, Boris. Doctor Zhivago. Trans. Richard Pevear and Larissa Volokhonsky. New York: Vintage, 2011.

Pamuk Orhan. Istanbul: Memories of a City. Trans. Maureen Freely. London: Faber and Faber, 2005.

Perec, Georges. "Space." Species of Spaces and Other Pieces. Trans. John Sturrock. London: Penguin, 1997, 80-92.

Perec, Georges. Life: A User's Manual. Trans. David Bellos. London: Vintage, 2008.

Pietrobruno, Sheenagh. "YouTube and the Social Archiving of Intangible Heritage." New Media \& Society 15:8 (2013), 1259-1276.

Ritter, Hellmut. "Die Mevlânafeier in Konya vom 11.-17. Dezember 1960." Oriens 15 (1962), 249-270.

Sagaster, Börte. “'Ich-Einer von Uns-Wir alle-Keiner von uns ...': Das Spiel mit Realität und Fiktion in Elif Şafaks Roman Bit Palas." Einheit und Vielfalt in der türkischen Welt. Eds. Hendrik Boeschoten and Heidi Stein. Turcologica Band 69 Wiesbaden: Harrasswitz, 2007, 272-280.

Scharf, Michael. "Bastard Out of Istanbul of Istanbul." Publishers Weekly 1o Mar. 2005. Web. 14Jun. 2013. 
Schimmel, Annemarie. Mystical Dimensions of Islam. Chapel Hill: University of North Carolina Press, 1975.

Sells, Michael A. "Early Muslim Spirituality and Mysticism." The Muslim Almanac. Ed. Azim A. Nanji. Detroit: Gale, 1996, 215-221.

Sells, Michael A. "Introduction." Early Islamic Mysticism. Sufi, Qur'an, Mi'Raj, Poetic and Theological Writings. Trans. Michael A. Sells. New York, Mahwah: Paulist, 1996, 11-27. "Sema". The Threshhold Society. Web. 2 Aug. 2016.

Shafak, Elif. Honour. London, New York: Penguin, 2012.

Shafak, Elif. Pinhan. Istanbul: Dogan Kitap, 1997.

Shafak, Elif. The Architect's Apprentice. London: Viking, 2014.

Shafak, Elif. The Bastard of Istanbul. New York: Penguin, 2007.

Shafak, Elif. The Flea Palace. Trans. Müge Göçek. London, New York: Marion Boyars, 2004.

Shafak, Elif. The Fourty Rules of Love. London: Viking, 2010.

Shafak, Elif. The Gaze. Trans. Brendan Freely. London, New York: Marion Boyars, 2004. Shafak, Elif. "The Politics of Fiction". TED. Jul. 2010. Web. 18 Nov. 2010.

Shafak, Elif. The Saint of Incipient Insanities. New York: Farrar, Straus, Giroux, 2004.

Shafak, Elif. Three Daughters of Eve. London, New York: Penguin, 2016.

Shah, Idries. Tales of the Dervishes. New York: Penguin Compass, 1967.

Suri, Manil. The Death of Vishnu. London: Bloomsbury, 2001.

Tekin, Latife. Berji Kristen: Tales from the Garbage Hills. Trans. Ruth Christie and Saliha Parker. London, New York: Marion Boyars, 1993.

Wallant, Edward Lewis. The Tenants of Moonbloom. New York: New York Review of Books, 1963.

Ware, Chris. Building Stories. London: Cape/Random House. 2012.

Zola, Émile. Pot Luck. Trans. Brian Nelson. Oxford, New York: Oxford UP, 1882/20o9. 